\title{
Ceftazidime in severe infections: a Swiss multicentre study
}

\author{
P. Francioli', M. Clément', S. Geroulanos', A. von Graevenitz', R. Luthys, \\ C. Regamey ${ }^{2}$, H. Stalder ${ }^{6}$, M. Vogt ${ }^{5}$ and F. A. Waldvogel ${ }^{7}$
}

${ }^{1}$ Division des Maladies Infectieuses, Département de Médecine Interne, Centre Hospitalier Universitaire Vaudois, Lausanne, 'Service de Médecine, Hôpital Cantonal, Fribourg, ${ }^{3}$ Chirurgische Klinik A, Universitätspital, Zürich 'Institut für Medizinische Mikrobiologie der Universität, Zürich, 'sMedizinische Poliklinik, Universitätspital, Zürich, 'Medizinische Klinik, Kantonsspital, Liestal and 'Division des Maladies Infectieuses, Hôpital Cantonal, Genève, Switzerland

\begin{abstract}
A total of 105 patients (mean age 57, range 15 to 90 ) with serious infections were treated with intravenous ceftazidime, usually $2 \mathrm{~g}$ 8-hourly. Most patients had complicating factors such as major surgery, cancer, chronic obstructive lung disease, catheters or anatomical abnormalities. Eighty-seven infectious episodes in 77 patients could be assessed for efficacy. Bacteraemia was diagnosed in $26 \%$ of these episodes. Seventy-five per cent of infections were due to Gram-negative bacteria, Pseudomonas aeruginosa being the most frequent. The major sites of infections were the lower respiratory tract (30), the urinary tract (28), the soft tissues (9), the biliary tract (4), bones (4) and the ears (4). Overall, $67 \%$ of the patients were cured, $20 \%$ improved, $7 \%$ relapsed and $6 \%$ failed to respond. Among the 27 infections due to Ps aeruginosa, only two failures (in the same patient) and four relapses were recorded. However, in the two failures and in three other cases with persistent Ps. aeruginasa colonisation, the organism had become resistant to ceftazidime. Three failures were recorded in the seven Staphylococcus aureus infections included in this study. Superinfection occurred in four patients. Adverse events included rash (6), Clostridium difficile toxin-induced diarrhoea (3), transaminase elevation (3), weakly positive Coombs test (10). Ceftazidime appears to be safe and effective for the treatment of severe Gram-negative infections, including those caused by Ps. aeruginosa.
\end{abstract}

\section{Introduction}

Ceftazidime is a new cephalosporin which combines stability against a wide range of $\beta$-lactamases and broad antibacterial spectrum in vitro (Neu \& Labthavikul, 1982).

Its high intrinsic activity against a wide range of both $\mathrm{Gram}$-positive and $\mathrm{Gram}$-negative organisms including Pseudomonas aeruginosa is of special interest for clinicians who have to treat patients with severe infections before results of cultures and sensitivities are known. In addition, and in contrast with most other cephalosporins, the low minimal inhibitory concentrations of the drug against most $P s$. aeruginosa strains suggest that infections due to this organism can possibly be treated with ceftazidime alone.

These favourable properties prompted us to set up a multicentre study to investigate the efficacy and toxicity of ceftazidime in a large number of patients with severe infections. 


\section{Patients and methods}

The study was carried out in three teaching hospitals (Geneva, Lausanne and Zürich) and two state hospitals (Fribourg and Liestal).

Patients with serious infections requiring treatment with a parenteral antibiotic were eligible for this study. Patients known to be hypersensitive to cephalosporins or who had a history of anaphylactic reaction to penicillin were excluded, as were pregnant women and patients with neutropenia.

The usual dosage regimen was $2 \mathrm{~g}$ eight-hourly of ceftazidime given intravenously by a bolus injection or infusion over a $15-$ to 20 -min period. When renal function was significantly impaired the dosage frequency was reduced to 12-hourly in patients with a glomerular filtration rate (GFR) of 30 to $15 \mathrm{ml} / \mathrm{min}$ and to 24 -hourly dosing in patients with a GFR of less than $15 \mathrm{ml} / \mathrm{min}$. The protocol specified that the duration of treatment should normally be between 7 and 10 days.

Samples for bacteriological culture and sensitivity testing were collected at the following times: before treatment, 2 to 5 days and 8 to 10 days after the start of treatment, 48 to $72 \mathrm{~h}$ after stopping treatment and if possible 1 to 2 weeks after stopping treatment.

Pathogens were considered to be responsible for an infection if they were grown from an appropriate specimen and if the clinical setting was consistent. For clinically well-established lower respiratory tract infections with sputum yielding several different organisms, it was not always possible to determine the pathogenic role of each. These few cases were assessed on clinical grounds only. Disc sensitivity was performed either by the Kirby-Bauer technique or the WHO-ICS method with discs containing $10 \mu \mathrm{g}$ of ceftazidime. The pathogens were considered to be sensitive if the zone diameter was greater than $14 \mathrm{~mm}$ (Kirby-Bauer) or greater than or equal to $19 \mathrm{~mm}$ (WHO-ICS). Minimal inhibitory concentrations were measured for most isolates by standard twofold serial dilution method with an inoculum of $10^{5}$ organisms per $\mathrm{ml}$.

All patients had blood and urine specimens taken for haematological and biochemical investigations at the following times: before treatment, 2 to 5 days and 8 to 10 days after the start of treatment and 1 to 3 days after the end of treatment. In addition, if there was any abnormality in the post-treatment sample, further samples were taken 1 to 2 weeks later.

Patients were considered as cured clinically when clinical abnormalities subsided with no evidence of infection when the drug was discontinued or during follow-up. They were considered as improved when clinical abnormalities subsided but with incomplete resolution of infection. Relapse was defined as improvement on therapy with reappearance during follow-up of an infection at the same site and isolation of the same organism. Failure was defined as no apparent response to therapy. In addition to the initial assessment made by each investigator all protocols were reviewed by one of us (P.F.).

\section{Results}

Sixty-two adult males and 43 adult females entered the study. One man was treated on three separate occasions and one woman twice, giving a total of 108 cases treated. The mean age for the males was 61.8 years (range 17 to 90 ) and for the females 52.0 years (range 15 to 83). Twenty-two males and nine females were more than 70 years of age.

Eighty-two patients received $2 \mathrm{~g} 8$-hourly of ceftazidime and nine patients $1 \mathrm{~g} 8$-hourly. Sixteen patients had pre-treatment renal impairment indicated by a decrease in creatinine clearance and/or increase in serum creatinine and thus the frequency of dosing was reduced. 
All patients were treated intravenously. In four patients this was changed to intramuscular administration. The duration of treatment with ceftazidime ranged from 1 to 53 days. Most patients (58) were treated for 8 to 14 days. Four were treated for less than 4 days, three because of early death and one because thetreatment was changed. Seventeen patients were treated for four to seven days, 15 for 15 to 21 days and 14 for more than 21 days. These 14 patients were treated for septic arthritis (2), complicated otitis externa (2), lung abscess (2) and one each for osteomyelitis, otitis media, mediastinitis, infected tumour, meningitis, intraabdominal abscess, skin ulcer and septicaemia.

The MICs (micrograms per millilitre) of the main pathogens were as follows: $E$. coli, $<0.03$ to 8.0 (mean: 0.07), Ps. aeruginosa, 0.05 to 4.0 (mean: 0.63), Klebsiella sp., 0.06 to 16 (mean: 0.11), Enterobacter sp., $<0.03$ to 0.25 (mean: 0.08), Staph. aureus, 4 to 16 (mean: $4 \cdot 5$ ).

Although all patients were included in the assessment of toxicity of ceftazidime, 28 cases had to be eliminated for the final assessment of efficacy, 4 because duration of treatment was too short, 9 because other antibiotics were administered, 4 because multisystem failure precluded any judgment on the efficacy of the drug, 7 because infection was ultimately not confirmed, and 4 because cultures obtained before initiation of therapy yielded ceftazidime-resistant organisms (3 Streptococcus faecalis, 1 Aspergillus fumigatus). Thus, from a total of 105 patients with 125 infections, 77 patients with 87 infections were assessable for efficacy (Table I). In over $80 \%$ of the cases the infection was judged as being severe by the clinician. The majority of patients were treated for lower respiratory tract infections (30) and urinary tract infections (28). In 22 of these 86 infections bacteraemia was demonstrated. Overall, $67 \%$ of the patients were cured, $20 \%$ improved, $7 \%$ relapsed and $6 \%$ failed to respond to ceftazidime.

\section{Pneumonias}

Twenty-four pneumonias were clinically assessable. Eleven were hospital-acquired, mostly after extensive neck (3) or thoracic (1) surgery for cancer, heart surgery (3) or major abdominal pathology (2). Two patients were intubated, one for a Guillain-Barré syndrome, the other after acute coronary bypass. Among the 13 community-acquired pneumonias, 4 were secondary to aspiration and 9 afflicted patients with various underlying debilitating diseases, such as chronic obstructive lung disease (6), cirrhosis (3), cardiac insufficiency (3), autoimmune (3) and neurological (3) disorders, cancer (3), and diabetes (1). Furthermore, 5 patients with pneumonia had already been treated unsuccessfully with antibiotics and 3 had cavitating lesions (Ps. aeruginosa 2, Enterobacter aerogenes 1 ). In three patients, bacteraemia was diagnosed before therapy started.

Fourteen pneumonias were due to Gram-negative bacteria, Ps. aeruginosa representing nine of them. Thirteen were cured or improved. Of the two patients who improved, one subsequently developed positive blood cultures for Bacteroides fragilis and Candida albicans due to a concomitant ischaemic colitis. One failure possibly due to the development of ceftazidime-resistant $P s$. aeruginosa was recorded in a patient with extensive neck surgery for metastatic cancer. Four out of the nine patients infected with $P$ s. aeruginosa remained colonized with the organism although infection was cleared clinically and radiologically. In three of the four patients with persisting Pseudomonas and in the above-mentioned failure the organisms had become resistant to ceftazidime. In the two instances in which the initial sensitive and subsequent resistant isolates were pyocin-typed, they were identical (Blaser et al., 1983). However, clinically, in only a single case did this resistance contribute to a definite clinical failure.

Failures were recorded in the two Staph aureus pneumonias, despite sensitivity to 
Tabłe I

\begin{tabular}{|c|c|c|c|c|}
\hline $\begin{array}{l}\text { Site of } \\
\text { infection (no.) }\end{array}$ & Pathogens & $\begin{array}{l}\text { No. of } \\
\text { cases } \\
\text { (no. with } \\
\text { bac- } \\
\text { teraemia) }\end{array}$ & Outcome & Remarks \\
\hline \multirow[t]{6}{*}{ Pneumonia (24) } & Ps aeruginosa & $9(1)$ & $\begin{array}{l}5 \text { cured } \\
3 \text { improved }\end{array}$ & $\begin{array}{l}\text { One case with superinfec- } \\
\text { tion with Bact. fragilis } \\
\text { and } C \text {. albicans }\end{array}$ \\
\hline & & & 1 failed & $\begin{array}{l}\text { Emergence of ceftazidime- } \\
\text { resistant } P \text {. aeruginosa }\end{array}$ \\
\hline & $\begin{array}{l}\text { E. coli } \\
\text { E. coli } \\
\text { A. calcoaceticus }\end{array}$ & $\begin{array}{l}1(1) \\
1(1)\end{array}$ & $\begin{array}{l}1 \text { cured } \\
1 \text { cured }\end{array}$ & \\
\hline & $\begin{array}{l}\text { K. oxytoca } \\
\text { Enterobacter sp. }\end{array}$ & $\begin{array}{l}1 \\
2\end{array}$ & $\begin{array}{l}1 \text { cured } \\
2 \text { cured }\end{array}$ & \\
\hline & Staph. aureus & 2 & $\begin{array}{l}1 \text { failed } \\
1 \text { failed }\end{array}$ & $\begin{array}{l}\text { Pleurotracheal fistula } \\
\text { Positive blood culture on } \\
\text { ceftazidime }\end{array}$ \\
\hline & $\begin{array}{l}\text { Sirep. pnewmoniae } \\
\text { Unidentified }\end{array}$ & $\begin{array}{l}3 \\
5\end{array}$ & $\begin{array}{l}3 \text { cured } \\
5 \text { cured }\end{array}$ & \\
\hline Bronchitis (6) & Unidentified & 6 & 6 improved & \\
\hline $\begin{array}{l}\text { Urinary tract } \\
\text { infections (28) }\end{array}$ & $\begin{array}{l}\text { E. coli } \\
\text { K. pneumoniae } \\
\text { Ps. aeruginosa }\end{array}$ & $\begin{array}{r}18(9) \\
5(1) \\
5(1)\end{array}$ & $\begin{array}{l}18 \text { cured } \\
5 \text { cured } \\
3 \text { cured } \\
2 \text { relapsed }\end{array}$ & $\begin{array}{l}\text { One case with bladder } \\
\text { diverticula }\end{array}$ \\
\hline \multirow[t]{2}{*}{$\begin{array}{l}\text { Biliary tract } \\
\text { infections (4) }\end{array}$} & E. coli & $2(2)$ & $\begin{array}{l}1 \text { cured } \\
1 \text { improved }\end{array}$ & Ultimately cured by surgery \\
\hline & $\begin{array}{l}\text { K. pneumoniae } \\
\text { Ps. aeruginosa }\end{array}$ & $\begin{array}{l}1(1) \\
1\end{array}$ & $\begin{array}{l}1 \text { improved } \\
1 \text { improved }\end{array}$ & $\begin{array}{l}\text { Ultimately cured by surgery } \\
\text { Ultimately cured by surgery }\end{array}$ \\
\hline Enterocolitis (1) & Salm. typhimurium & 1 & 1 improved & $\begin{array}{l}\text { Carrier at the end of } \\
\text { ceftazidime }\end{array}$ \\
\hline \multirow[t]{2}{*}{ Peritonitis (2) } & Staph. aureus & 1 & 1 failed & $\begin{array}{l}\text { Development of } S \text {. aureus } \\
\text { peritoneal abcess while } \\
\text { on ceftazidime }\end{array}$ \\
\hline & $K$. pneumoniae & 1 & 1 failed & $\begin{array}{l}\text { Development of ceftaridime- } \\
\text { resistant Citrobacter and } \\
\text { later Str. faecalis intra- } \\
\text { abdominal abscess }\end{array}$ \\
\hline External otitis (4) & Ps. aeruginosa & 4 & $\begin{array}{l}2 \text { cured } \\
2 \text { relapsed }\end{array}$ & $\begin{array}{l}\text { Ps. aeruginosa remained } \\
\text { sensitive }\end{array}$ \\
\hline Osteoarthritis (2) & Ps. aeruginosa & 2 & 2 cured & $\begin{array}{l}\text { + Debridement and } \\
\text { gentamicin beads }\end{array}$ \\
\hline Diabetic foot (2) & $\begin{array}{l}\text { Ps. aeruginosa } \\
\text { Group B strep- } \\
\text { tococcus }\end{array}$ & $1(1)$ & $\begin{array}{l}1 \text { improved } \\
1 \text { improved }\end{array}$ & \\
\hline \multirow[t]{2}{*}{ Surgical wounds (4) } & Ps. aeruginosa & 4 & $\begin{array}{l}1 \text { cured } \\
2 \text { improved }\end{array}$ & $\begin{array}{l}\text { + Surgical debridement } \\
\text { + Surgical debridement } \\
\text { (ultimately cured) }\end{array}$ \\
\hline & & & 1 failed & $\begin{array}{l}\text { Development of ceftazidime- } \\
\text { resistant Ps. aeruginosa }\end{array}$ \\
\hline \multirow[t]{2}{*}{ Cellulitis (4) } & Staph. aureus & 3 & $\begin{array}{l}2 \text { cured } \\
1 \text { improved }\end{array}$ & \\
\hline & $\begin{array}{l}\text { Staph. aureus, E. coli } \\
\text { Salm. typhimurium }\end{array}$ & $i 1$ & 1 cured & + Debridement and graft \\
\hline
\end{tabular}


Table I

\begin{tabular}{|c|c|c|c|c|}
\hline $\begin{array}{l}\text { Site of } \\
\text { infection (no.) }\end{array}$ & Pathogens & $\begin{array}{l}\text { No. of } \\
\text { Cases } \\
\text { (no. with } \\
\text { bac- } \\
\text { teraemia) }\end{array}$ & Outcome & Remarks \\
\hline $\begin{array}{l}\text { Mediastinitis (1) } \\
\text { Gonococcaemia (1) } \\
\text { Epididymitis (1) }\end{array}$ & $\begin{array}{l}\text { Provid. stuartii } \\
N \text {. gonorrhoeae } \\
\text { E. coli }\end{array}$ & $\begin{array}{l}1(1) \\
1(1) \\
1\end{array}$ & $\begin{array}{l}1 \text { cured } \\
1 \text { cured } \\
1 \text { cured }\end{array}$ & $\begin{array}{l}\text { Cotrimoxazole treatment } \\
\text { during follow-up }\end{array}$ \\
\hline Meningitis (1) & Ps. aeruginosa & 1 & 1 cured & $\begin{array}{l}\text { Developed while patient } \\
\text { was on ticarcillin } \\
\text { and tobramycin }\end{array}$ \\
\hline \multirow[t]{2}{*}{$\begin{array}{l}\text { Intravenous } \\
\text { catheter (2) }\end{array}$} & K. pneumoniae & $1(1)$ & 1 relapsed & $\begin{array}{l}\text { Re-infection of new } \\
\text { catheter while on ceftazidine }\end{array}$ \\
\hline & Ent. cloacae & $1(1)$ & 1 cured & \\
\hline
\end{tabular}

ceftazidime. One patient had a pleurotracheal fistula, secondary to extensive thoracic surgery for lung cancer. The other developed bacteraemia after 5 days of treatment and was subsequently cured by other antibiotics.

Eight patients with community-acquired pneumonia had sputum growing mixed bacterial flora, including Str. pneumoniae in three instances. All were cured.

Three patients with pneumonia died, but in one instance only did infection contribute to the death. Two additional deaths from pneumonia, both due to Strep. pneumoniae, have not been included because they occurred during the first $24 \mathrm{~h}$. Two additional failures were observed in patients infected with pathogens which turned out to be resistant to ceftazidime (Str. faecalis, Aspergillus fumigatus) and were therefore not included.

\section{Bronchitis}

Six cases of severe bronchitis with abundant purulent sputum in patients with severe predisposing pulmonary diseases improved markedly on ceftazidime. Organisms isolated from sputum included a variety of Gram-negative organisms ( $E$. coli, Enterobacter sp., $K$. pneumoniae, $H$. influenzae) in mixed cultures, but their pathogenic role in each individual case was difficult to assess.

\section{Urinary tract infections}

Urinary tract infections, defined as $>10^{5}$ bacteria/ml of urine, accounted for 28 cases. Twenty were considered as upper tract infections because of fever, loin pain and positive blood cultures in 12 instances. Sixteen cases had underlying factors either predisposing to infection or complicating treatment (Foley catheters 7, urinary tract abnormalities 7, renal transplant 2). The pathogens were the usual bacteria involved in urinary tact infections, Ps. aeruginosa being somewhat over-represented because of the drug studied. Twenty-four were clinically and bacteriologically cured with a negative urine culture obtained at least 1 week after treatment stopped. Two cases were clinically cured but bacteriologically unassessable because they received other antibiotics during the follow-up period. Two relapses occurred, both in patients with Ps. aeruginosa infections. Only one 
of the two patients had an underlying urinary tract abnormality. In both cases the initial and final isolates were sensitive to ceftazidime.

\section{Biliary tract and abdominal infections}

Four patients had biliary tract infection, three of them with positive blood cultures. In the fourth, the bile obtained by a percutaneous drain was positive for $P s$. aeruginosa. One patient was cured with antibiotic alone, while the other three improved markedly on therapy and were eventually cured when surgery was performed. The patient infected with $K$. pneumoniae still harboured sensitive $K$. pneumoniae in the bile obtained during an operation performed after 2 weeks of therapy. Two patients were treated with ceftazidime because of fever occurring after abdominal surgery for perforated ulcer and pancreatitis with intra-operative cultures positive for Staph aureus and $K$. pneumoniae, respectively. On therapy, they developed clinically detectable abdominal abscesses due to Staph. aureus in one case and to ceftazidime-resistant Citrobacter sp. in the other case. One patient with Salmonella typhimurium enterocolitis was cured clinically but still harboured Salm. typhimurium at the end of a 14 day course of ceftazidime.

\section{External otitis}

Four patients had severe purulent Ps. aeruginosa otitis with chondritis and abscesses. Two had had tympanoplasty. Three had been treated unsuccessfully by surgery and other antibiotics. All responded to ceftazidime, but two relapsed after 15 and 90 days despite 3 and 6 weeks of ceftazidime therapy, respectively. In both cases, the Ps. aeruginosa were still sensitive to ceftazidime.

\section{Skin and wound infections}

Four patients had surgical wound infections. Three improved on ceftazidime in association with surgical debridement and were eventually cured, one at the time when the drug was stopped, the other two a few weeks later without further therapy. One patient with cheek cancer and concomitant bacteraemic Ps. aeruginosa pneumonia failed to respond, developed resistant $P$ s. aeruginosa wound infection and eventually died from multisystem failure. Four patients had severe cellulitis complicating underlying skin diseases. Two were cured and one improved with ceftazidime alone. The fourth required surgical debridement and skin graft.

\section{Osteoarthritis}

Two patients with Ps. aeruginosa chronic osteoarthritis were cured (with a follow-up of 3 and 6 months) with surgical debridement, local gentamicin beads (removed after 10 and 30 days, respectively) and 6 weeks of ceftazidime therapy. Two patients with diabetic foot infections were admitted in hospital for amputation. On ceftazidime they improved markedly and amputation could be postponed.

\section{Miscellaneous infections}

Two intravenous catheter septicaemias and one case each of mediastinitis, epididymitis, gonococcaemia and meningitis were also treated with ceftazidime. All except one were 
cured. One patient with intravenous catheter-related $K$. pneumoniae septicaemia had a clinical relapse with $K$. pneumoniae infection of a newly placed catheter. The organism was still sensitive to ceftazidime.

Of note is the cure of a post-traumatic ticarcillin-resistant Ps. aeruginosa meningitis which developed while the patient was on ticarcillin and tobramycin. Forty-eight hours after initiation of therapy the CSF ceftazidime level was $40 \mathrm{mg} /$, while it fell to $<1 \mathrm{mg} / \mathrm{l}$ after 3 weeks of therapy when signs of meningeal inflammation had disappeared.

\section{Adverse events}

Superinfection occurred in 4 patients (C. albicans and Bact. fragilis septicaemia, Candida krusei urine infection, Str. faecalis bacteraemia, Citrobacter sp. intra-abdominal abscess) and colonization with Str. faecalis in two patients (urine, wound).

In addition, 10 patients experienced adverse events which were attributed to ceftazidime. In one patient, there were four repeated occurrences until a central venous two cases. Skin rashes were observed in six cases (associated with pruritus in one case). In one patient, treatment was continued and the rash disappeared. With the other two patients, the rash did not disappear until treatment was stopped, but the drug was discontinued because it was no longer needed therapeutically and not because of the rash. One patient developed a fever which was well tolerated despite further ceftazidime treatment.

There were six cases of intravenous catheter thrombophlebitis possibly related to ceftazidime. In one patient, there were four repeated occurrences until a central venous catheter was placed. Five cases of diarrhoea were observed. $\mathrm{Cl}$. difficile and its toxin were identified in the stools of the three patients in whom it was looked for. Vancomycin was given for the first two, although symptoms had already started to resolve in one of them. The diarrhoea resolved spontaneously after ceftazidime was stopped in the last case. Increase in serum creatinine which could possibly be related to ceftazidime was noted in one patient, but this patient already had renal impairment secondary to hypertension, and deterioration could be attributed to several conditions other than ceftazidime.

Slight changes in the results of liver function tests were noted in three patients. In one, SGPT returned to normal 10 days after ceftazidime was stopped. In the other two patients with increase in both SGOT and SGPT, further follow-up was not available. No prothrombin time alteration was observed. A weakly positive direct Coombs test occurred in ten patients, none of whom had evidence of haemolysis.

\section{Discussion}

The present study demonstrates the clinical efficacy of ceftazidime in various severe infections occurring in debilitated patients and due to a wide range of bacteria. Overall, $87 \%$ of patients were cured or improved.

Of special interest are the good results obtained in Ps. aeruginosa infections with ceftazidime as single agent. Among the 27 infections due to this pathogen in the present series, there were only 2 failures and 4 relapses. The two failures were recorded in the same patient, who had simultaneously pneumonia and a wound infection, with the appearance of ceftazidime-resistant Ps. aeruginosa at both sites during treatment. Four relapses occurred, two in patients with severe otitis, a disease known to be very difficult to cure, and two in patients with urinary tract infections, one of whom had underlying urinary tract abnormality. In all four cases, the Ps. aeruginosa isolates were still sensitive 
to ceftazidime at the time of relapse. The other 21 Ps. aeruginosa infections were successfully treated with ceftazidime (in association with surgery when indicated), and included problem infections such as excavating pneumonia, osteoarthritis, severe soft tissue infections, external otitis and meningitis. The rapid development during treatment of ceftazidime-resistant $P$ s. aeruginosa at the site of infection, as observed in the sputum of 4 out of 9 patients with Ps. aeruginosa pneumonia, is a cause of concern. Similar observations have been reported by others for Ps. aeruginosa as well as for Enterobacter (Eron et al., 1983). The pyocin-typing of Ps. aeruginosa performed in two of our cases suggests that the development of resistance was due to the induction of resistance in the original sensitive strain rather than to the selection of a natural resistant strain or to the acquisition of a resistant strain from the environment. However, in one patient only did this phenomenon contribute to a clinical failure, and its clinical importance remains to be defined.

The minimal inhibitory concentrations of ceftazidime for Staph. aureus are notably higher than those of other cephalosporins (van Klingerer (1981)). In the present study, we treated seven Staph. aureus infections. Three of the four cases of cellulitis complicating various skin disorders were cured or improved by ceftazidime alone, and one with ceftazidime combined with surgical debridement. In contrast, ceftazidime failed in the two Staph. aureus pneumonias, in one case possibly because of the presence of an anatomical defect, but in the other case without detectable factors contributing to the persistence of infection. The latter case developed Staph. aureus bacteraemia while receiving ceftazidime and was switched to flucloxacillin and ultimately cured. Another failure was recorded in a patient who presented with Staph. cureus peritonitis following a perforated duodenal ulcer. On ceftazidime therapy he developed an intra-abdominal abscess due to Staph. aureus.

Ceftazidime was well tolerated in all except five patients ( 3 with rashes and 2 with diarrhoea), who required discontinuation of the drug. There were three cases of $\mathrm{Cl}$. difficile toxin-induced diarrhoea. In contrast with some other new cephalosporins, no prothrombin time alteration was observed. Superinfection occurred in four cases and colonization with resistant organisms in two cases (excluding the above-mentioned Ps. aeruginosa cases).

In conclusion, ceftazidime proved to be safe and effective for the treatment of various severe infections due to Gram-negative bacteria including Ps. aeruginosa, but failures observed in three out of seven Staph. aureus infections in the present study gives rise to concern. The clinical importance of emergence of resistance during therapy should be further explored.

\section{References}

Neu, H. C. \& Labthavikul, P. (1982). Antibacterial activity and $\beta$-lactamase stability of ceftazidime, an aminothiazolyl cephalosporin potentially active against Pseudomonas aeruginosa. Antimicrobial Agents and Chemotherapy 21, 11-18.

Blaser, J., Bauernfeind, A., Vogt, M. \& Lüthy, R. Monotherapie von systemischen Pseudomonas aeruginosa Infektionen mit Ceftazidim: Ursachen von therapeutischen Misserfolgen. Deutsche Medizinische Wochenschrift. (In press.)

Eron, L. J., Goldenberg, R. I., Park, C. H. \& Poretz, D. M. (1983). Ceftazidime therapy of serious bacterial infections. Antimicrobial Agents and Chemotherapy, 23, 236-41.

Van Klingeren, B. (1981). An in-vitro comparison of new cephalosporins with special reference to Pseudomonas aeruginosa. Journal of Antimicrobial Chemotherapy 8 Suppl. B, 97-105. 